\title{
Enhancing Nocturnal Habitat for the American Woodcock on Louisiana Wintering Grounds
}

JAMES C. HAYNES, ${ }^{1}$ Department of Biology, University of Louisiana at Monroe, 700 University Avenue, Monroe, $L A$ 71209, USA

JEFFREY P. DUGUAY, Louisiana Department of Wildlife and Fisheries, Baton Rouge, LA 70808, USA

KIM MARIE TOLSON, Department of Biology, University of Louisiana at Monroe, 70o University Avenue, Monroe, LA 71209, USA

\begin{abstract}
American woodcock (Scolopax minor; hereafter, woodcock) have experienced long-term population declines across much of their breeding distribution since 1968. Previous research suggests that nocturnal habitat availability on the wintering grounds is important to wintering woodcock survival. We compared 4 different land management techniques: mowing, burning, disking, and a mow/burn combination for enhancing nocturnal habitat for woodcock in south-central Louisiana. From 2011-2013, we monitored study plots during overcast nights throughout winter months. We detected woodcock most frequently in both the burn and mow treatments and least frequently in the disk treatment. The total numbers of woodcock we captured and flushed were 13 times greater in the burn treatment than in the disk treatment. We captured 24 times more juvenile woodcock in the mow and burn treatments than in the disk treatment. We captured 12 times more female woodcock in the burn treatment than in the disk treatment, whereas we captured 9 times more male woodcock in the mow treatment than in the disk treatment. Our results suggest that suitable nocturnal habitat for woodcock on the wintering grounds in south-central Louisiana can be enhanced by burning and/or mowing.
\end{abstract}

Proceedings of the American Woodcock Symposium 11: 130-135

KEY WORDS: American woodcock, habitat, modeling, nocturnal, Scolopax minor, wintering, Louisiana

The American woodcock (Scolopax minor; hereafter, woodcock) is migratory game bird in eastern North America, and is managed on the basis of 2 regions, Eastern and Central (Seamans and Rau 2016). Long-term population declines on large portions of the breeding grounds have been documented since the beginning of singing-ground surveys in 1968 (Seamans and Rau 2016). Due to these long-term declines, woodcock are currently listed as a species of high concern by the U.S. Shorebird Conservation Plan (U.S. Shorebird Conservation Plan 2001), and as a game bird below desired population size by the U.S. Fish and Wildlife Service (U.S. Fish and Wildlife Service 2004). These population declines are believed to be largely due to habitat loss created by current agriculture and societal land-use practices resulting in a reduction in adequate early successional forest vegetation types (Kelley et al. 2008). Low winter period survival rates of $72 \pm 5 \%$ may partially explain the long-term declines in woodcock populations (Pace 2000). Suitable nocturnal habitat availability, not hunting mortality, is suspected to play the largest role in woodcock survival on the wintering grounds (Krementz et al. 1994, Pace et al. 2000, Pace 2000, Glenn et al. 2004, but see Berdeen and Krementz 1998). This low winter survival suggests that placing a greater emphasis on providing or enhancing nocturnal habitat for woodcock on the wintering grounds may be warranted.

To manage for woodcock, appropriate diurnal and nocturnal habitat must be provided within $700 \mathrm{~m}$ of each other (Berdeen and Krementz 1998). Woodcock use forests for diurnal and nocturnal cover, whereas early suc-

1 email: codyh@mdwfp.state.ms.us

https://doi.org/10.24926/AWS.o119 CC BY 4.0 
cessional openings provide foraging grounds for wintering woodcock at night (Dyer and Hamilton 1974, Straw et al. 1994, Berdeen and Krementz 1998, Krementz 2000, Kelley et al. 2008). Although habitat preferences of woodcock have been studied elsewhere, there is little research available concerning woodcock response to management practices designed to create early successional nocturnal habitat on the wintering grounds (Krementz 2000, Welch et al. 2001, Glenn et al. 2004; Berry et al. 2006). Welch et al. (2001) examined woodcock response to manipulated, early successional cover types within the Eastern Management Region and concluded that some manipulative practices, namely burning and herbicide application, could be used to create woodcock habitat. However, the Welch et al. (2001) study was limited in scope and additional research on winter habitat management techniques is needed. Therefore, we examined woodcock response to 4 management practices designed to create early successional nocturnal cover as woodcock habitat on the wintering grounds within the Central Management Region.

\section{Study Area}

We conducted our study on the Sherburne Wildlife Management Area (SHWMA) located in the Morganza Flood Way system of the Atchafalaya Basin in south-central Louisiana. SHWMA is comprised of 17,276 ha of state
(SHWMA) and federal lands (Atchafalaya National Wildlife Refuge and U.S. Army Corps of Engineers land) and lies within Pointe Coupee, St. Martin, and Iberville parishes. SHWMA is managed by the Louisiana Department of Wildlife and Fisheries (LDWF 2019).

SHWMA was largely comprised of bottomland hardwood forest dominated by cottonwood-sycamore (Populus deltoides - Platanus occidentalis), oak-gum-hackberry-ash (Quercus spp. - Nyssa spp. - Celtis laevigata - Fraxinus spp.), overcup oak-bitter pecan (Quercus lyrata - Carya aquatica), and willow-cypress (Salix nigra - Taxodium distichum) tree species associations (Eyre 1980). There were about 100 ha of fallow fields located within the north-central portion of the area. Our study site was a 25.9 ha fallow field centrally located within the larger fallow field complex and surrounded by mature trees separating it from other nearby fallow fields (Fig. 1). Our study site had not been treated for several growing seasons and was dominated by saplings. The site contained even-aged early successional tree species dominated by cottonwood-sycamore-Chinese tallow (Triadica sebifera; $2-5 \mathrm{~cm}$ in diameter and 3-5 $\mathrm{m}$ tall), grasses, and forbs.

\section{Methods}

We selected 4 treatments to create nocturnal habitat: mow, burn, disc, and a mow/burn combination. We also con-

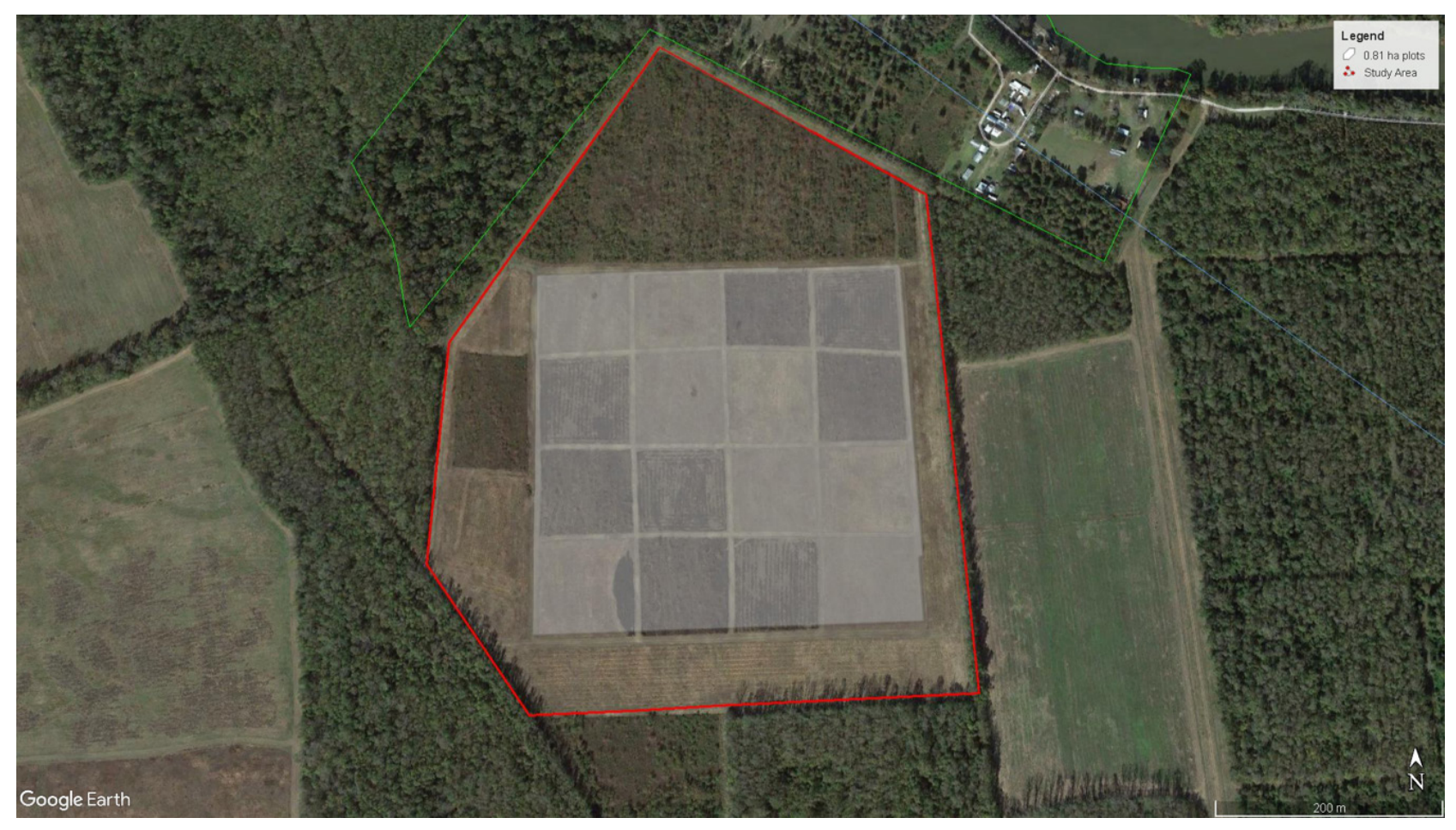

Figure 1. American woodcock nocturnal habitat study site at Sherburne Wildlife Management Area, Pointe Coupee Parish, Louisiana, USA. 
sidered a control treatment; however, due to the diameter of existing trees within the study area, we elected to reset succession within the entire study area as existing trees had already reached the capabilities of available equipment necessary to conduct the management. We replicated each treatment 4 times, thus creating 160.81 -ha study plots. The 16 study plots were arranged in a $4 \times 4$ grid pattern located near the center of the 25.9-ha study site. The arrangement of treatments was randomly selected for the northern-most row of plots. We rotated treatments for subsequent rows of plots so that similar treatments would not be adjacent to each other, thus preventing plot juxtaposition from becoming a potential woodcock selection factor (Berdeen and Krementz 1998). Treatment applications within plots were not altered between years and remained the same for both study years.

We created the study plots in the fall of 2011 by disking a ca. 5-m border around each of the 16 plots. We applied treatments in October of each year (2011 and 2012). We set the mower deck height to $35-40 \mathrm{~cm}$ for the mow treatments, which resulted in even-height vegetation throughout the treatment. We created disk treatments by initially mowing followed by a thorough and deep $(\geq 10 \mathrm{~cm})$ disking, resulting in no standing woody vegetation. We applied Reward@ (Syngenta), a herbicide with diquat, at a concentration of 1.33 1/o.40 ha to all treatments requiring a burn (burn and combination of mow/burn treatments) before burning to increase fuel load. We conducted controlled burns in late October of both seasons.
We captured woodcock by night-lighting (Rieffenberger and Kletzly 1967) from an ATV in our study plots from mid-November through mid-February of 2011-2012 and 2012-2013. We sexed, aged (Martin 1964, Artmann and Schroeder 1976), and fitted each captured bird with a United States Geological Survey (USGS) aluminum leg band. We searched study plots by completing 2 passes at a constant speed through each row of study plots. If we captured a marked woodcock twice on the same night, we excluded the second capture in our analysis. When woodcock flushed and were not captured, we recorded flushes in the plot they flushed from. We recorded all detections by treatment type.

We measured the vegetative composition of all plots to characterize vegetative structure of each treatment but not to reflect woodcock selection of specific vegetative composition. We characterized the vegetative structure for each treatment type by measuring vegetation using a $0.5 \times 1 \mathrm{~m}$ frame at 5 locations within each study plot. We measured vegetation during the third week of February of each year. We randomly selected the starting location on the west end of the plot, then recorded data every $10 \mathrm{~m}$ moving easterly from there. In each frame, we visually estimated percent live grass, dead grass, herbaceous vegetation, bare soil, standing woody vegetation, non-standing woody vegetation, and vine. We took 5 measurements of the height of woody stems, dead grass, and vines to the nearest $\mathrm{cm}$. We used SAS version 9.1 for all data analysis (SAS 2003). We ran PROC GLM with year as a random variable to examine for possible interaction between captures and flushes,

Table 1. American woodcock nocturnal habitat treatment (Mow, Burn, Mow/Burn, and Disk) selection results at Sherburne Wildlife Management Area, Pointe Coupee Parish, Louisiana, USA, during winters of 2011-2012 and 2012-2012. Post-hoc analysis was performed using the Tukey HSD test with $\alpha=0.05$, and variables with the same letter (Post-hoc) are not statistically significantly different from one another.

\begin{tabular}{|c|c|c|c|c|c|c|c|c|c|}
\hline \multirow[b]{2}{*}{ Variable } & \multirow[b]{2}{*}{$P$-value } & \multicolumn{2}{|c|}{ Mow } & \multicolumn{2}{|c|}{ Burn } & \multicolumn{2}{|c|}{ Mow/Burn } & \multicolumn{2}{|c|}{ Disk } \\
\hline & & $n$ & Post-hoc & $n$ & Post-hoc & $n$ & Post-hoc & $n$ & Post-hoc \\
\hline \multicolumn{10}{|l|}{$2011-2013$} \\
\hline Capture $^{\mathrm{a}}$ & 0.023 & 100 & $\mathrm{AB}$ & 135 & A & 68 & $\mathrm{AB}$ & 13 & $\mathrm{~B}$ \\
\hline Flush & $<0.001$ & 117 & $\mathrm{AB}$ & 170 & $\mathrm{~A}$ & 55 & $\mathrm{BC}$ & 8 & $\mathrm{C}$ \\
\hline Adult & 0.068 & 16 & $\mathrm{AB}$ & 38 & A & 25 & $\mathrm{AB}$ & 4 & $\mathrm{~B}$ \\
\hline male & 0.217 & 7 & $\mathrm{~A}$ & 12 & A & 10 & A & 2 & A \\
\hline female & 0.034 & 9 & $\mathrm{AB}$ & 26 & A & 15 & $\mathrm{AB}$ & 2 & $\mathrm{~B}$ \\
\hline Juvenile & 0.027 & 84 & A & 97 & $\mathrm{~A}$ & 43 & $\mathrm{AB}$ & 9 & $\mathrm{~B}$ \\
\hline male & 0.006 & 49 & $\mathrm{~A}$ & 38 & $\mathrm{AB}$ & 20 & $\mathrm{AB}$ & 4 & $\mathrm{~B}$ \\
\hline female & 0.084 & 35 & $\mathrm{AB}$ & 59 & A & 23 & $\mathrm{AB}$ & 5 & $\mathrm{~B}$ \\
\hline All males & 0.009 & 56 & $\mathrm{~A}$ & 50 & A & 30 & $\mathrm{AB}$ & 6 & $\mathrm{~B}$ \\
\hline All females & 0.039 & 44 & $\mathrm{AB}$ & 85 & A & 38 & $\mathrm{AB}$ & 7 & $\mathrm{~B}$ \\
\hline
\end{tabular}


and by sex and age class. We used a Tukey post-hoc analysis to examine differences in woodcock use among treatment types.

\section{Results}

We captured 316 woodcock (Table 1), 5 of which were recaptures from a previous year or a separate night, and we flushed 350 woodcock. Most captures $(n=233)$ were hatch-year (HY or juvenile) woodock. We captured 142 male woodcock, of which 31 were after-hatch-year. We also captured 174 female woodcock, of which 52 were after-hatch-year.

We captured woodcock more often in the burn treatment ( $n=135 ; 42.7 \%$ of captures; Table 1 ) than in the disk treatment ( $n=13 ; 4.1 \%$ of captures). There were no statistically significant differences in the number of woodcock captured in the mow ( $n=100 ; 31.6 \%$ of captures) and mow/burn ( $n=68 ; 21.5 \%$ of captures) treatments compared with the number captured in the other treatments $\left(\mathrm{F}_{7,24}=2.93, P=0.023\right)$. We also flushed more woodcock in the burn $(n=170 ; 48.6 \%$ of flushes $)$ and mow $(n=117$; $33.4 \%$ of flushes) treatments than in the disk $(n=8 ; 2.3 \%$ of flushes) treatment, and the number of woodcock flushed in the burn treatment was greater than the number flushed in the mow/burn ( $n=55 ; 15.7 \%$ of flushes) treatment $\left(\mathrm{F}_{7,24}\right.$ $=6.68, P<0.001$; Table 1). There was a treatment-by-year effect $(P=0.0029)$ for 1 combination of treatments, with significantly more woodcock flushed in the mow treatment in 2012 than in 2013.

The number of adult woodcock we captured did not differ among treatments $\left(\mathrm{F}_{7,24}=2.23, P=0.068\right.$; Table 1). We captured more juvenile woodcock in the burn $(n=97$; $41.6 \%$ of captures) and mow ( $n=84 ; 36.1 \%$ of captures) treatments than in the disk ( $n=9 ; 3.9 \%$ of captures) treatment. The number of juvenile woodcock captured in the mow/burn ( $n=43 ; 18.5 \%$ of captures) treatment did not differ from the number captured in the other treatments $\left(\mathrm{F}_{7,24}=2.83, P=0.027\right)$. We captured more male woodcock in the mow ( $n=56 ; 39.4 \%$ of captures) and burn $(n=50$; $35.2 \%$ of captures) treatments than in the disk $(n=6 ; 4.2 \%$ of captures) treatment, whereas the number of woodcock we captured in the mow/burn ( $n=30 ; 21.1 \%$ of captures) treatment did not differ from the number captured in the other treatments $\left(\mathrm{F}_{7,24}=3.60, P=0.009\right)$. We captured more female woodcock in the burn treatment $(n=85$; $48.9 \%$ of captures) than the disk treatment ( $n=7 ; 4.0 \%$ of captures). The number of female woodcock we captured in the mow ( $n=44 ; 25.3 \%$ of captures) and mow/burn ( $n=38 ; 21.8 \%$ of captures) treatments did not differ from the number we captured in the burn or disk treatments $\left(\mathrm{F}_{7,24}=2.59, P=0.039\right)$. The number of adult male woodcock we captured did not differ among treatments $(n=31$; $\mathrm{F}_{7,24}=1.49, P=0.217$ ). We captured adult female woodcock more often in the burn ( $n=26 ; 50.0 \%$ of captures) than in the disk ( $n=2 ; 3.4 \%$ of captures) treatment. The number of adult female woodcock we captured in the mow ( $n=9 ; 17.3 \%$ of captures) and mow/burn $(n=15 ; 28.8 \%$ of captures) treatments did not differ from the number we captured in the burn or disk treatments $\left(\mathrm{F}_{7,24}=2.66\right.$, $P=0.034)$. We captured juvenile male woodcock more often in the mow ( $n=49 ; 44.1 \%$ of captures) than in the disk ( $n=4 ; 3.6 \%$ of captures) treatment. The number of juvenile male woodcock we captured in the burn $(n=38$; $34.2 \%$ of all captures) and mow/burn $(n=20 ; 18.0 \%$ of all captures) did not differ from the number we captured in the mow and disk treatments $\left(\mathrm{F}_{7,24}=3.82, P=0.006\right)$. The number of juvenile female woodcock we captured did not differ among treatments $\left(\mathrm{F}_{7,24}=2.09, P=0.084\right)$.

The burn treatment was characterized by tall $(3.8 \mathrm{~m})$ woody vegetation and dead clump grasses with patches of bare soil (53\%). The mow treatment likewise had vertical structure that consisted of dead clump grasses and patches of bare soil (15\%). The mow/burn treatment had considerably more bare soil ( $42 \%)$ than did the mow treatment, but lacked vertical structure. Likewise, the disk treatment was characterized by bare soil (58\%) with little vertical structure (Figs. 2 \& 3).

\section{Discussion}

Our results suggest that both burn and mow treatments are suitable for enhancing nocturnal woodcock habitat in south-central Louisiana. We found that woodcock avoided treatments with little structural cover (i.e., disk and mow/ burn treatments) and favored treatments with vertical cover and patches of bare soil (i.e., burn and mow treatments). Although the mow treatment only consisted of $15 \%$ bare soil, apparently this was sufficient for foraging; probe holes were commonly found within this treatment. Berdeen and Krementz (1998) reported that woodcock in the Georgia Piedmont used fields with bare soil and high foliar volume in the 0.8-2.0-m stratum. In contrast, Glenn et al. (2004) found woodcock in eastern Texas used nocturnal sites with bare soil and overhead cover in the 0.26$0.75-\mathrm{m}$ stratum. Both our burn and mow treatments provided patches of bare soil and overhead cover. Although mow treatments did not provide foliar volume above $0.5 \mathrm{~m}$, woody debris both standing and on the ground and dead clump grasses likely provided adequate vertical cover while also allowing feeding. Studies in Virginia (Krementz et al. 1995), North Carolina (Stribling and Doerr 1985, Blackman et al. 2013), and Arkansas (Krementz et al. 2014) have reported woodcock use of agricultural fields with ridge/furrow topography and residual vegetation that likely provides a better vertical cover component than did our disk treatment.

Vegetative structure in the burn plots was noticeably different than vegetative structure in the mow plots, with greater woody vegetation height and more bare soil in 
the burn than mow plots. As did Glenn et al. (2004) and Berdeen and Krementz (1998), we found woodcock also used treatments with taller woody vegetation. Woodcock selection of nocturnal sites may be dependent on earthworm abundance (Dyer and Hamilton 1974, Blackman et al. 2012), microclimate (Stribling and Doerr 1985, Blackman et al. 2012), protection from predators (Berdeen and Krementz 1998, Glenn et al. 2004), or some combination of these factors. Although we did not measure earthworm abundance, we think it is unlikely that earthworm abundance differed among treatments, at least for the burn, mow, and mow/burn treatments. Treatments were all created in the same 25.9-ha study area and with the exception of the disk treatment there was little if any soil disturbance when treatments were applied. The major difference among treatments was the amount and structure of cover available. Woodcock at our study site may be selecting habitats based on thermal cover and protective cover from predators. Although burn, mow, and mow/burn treatments typically did not differ significantly in terms of number of woodcock captured, there was a general trend for a greater percentage of woodcock captures in both the burn (range: $34.2 \%-48.9 \%$ ) and mow plots (range: $17.3 \%-44.1 \%$ ) than the mow/burn (range: $15.7 \%-32.25$ ) plots. This could be because the mow/burn plots tended to have less vegetative cover than either the mow or burn plots.

Our study site consisted a 25.9-ha fallow field with replications of 4 treatments within this fallow field. Future studies should consider replicating treatments at sites that

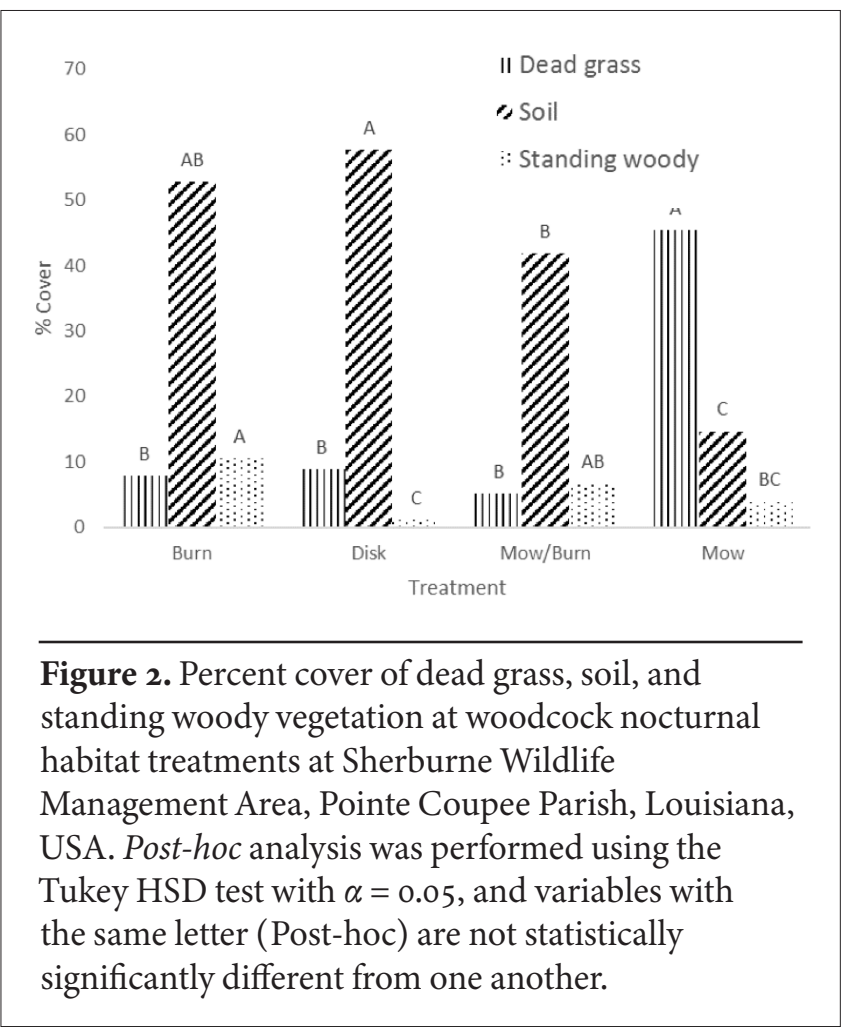

are geographically separated to avoid possible confounding results due to pseudoreplication.

\section{Management Implications}

Both mow and burn treatments were used more frequently by woodcock than mow/burn and disc treatments. The combination of vertical structure and bare ground likely provides protection from predators while still allowing woodcock to forage. However, annual application of either treatment will likely result in loss of important vertical cover. Repeated annual mowing typically results a reduction of woody cover and increased grass cover (Harper 2007), likely increasing woodcock exposure to predators and reducing foraging opportunities. If mow treatments are implemented, implementation should be on a $\geq 2$-year rotation with deck height set $\geq 40 \mathrm{~cm}$. Whereas both mow and burn treatments can offer high-quality woodcock habitat, sustainable habitat will most likely be achieved using both mow and burn treatments on a rotational basis. For example, a field can be mowed one fall, allowed to remain fallow the next fall, and then burned the third fall. This rotation should reduce the intrusion of grasses while maintaining woody cover. Management suggestions discussed here should be coupled with those of Krementz (2000), ensuring nocturnal habitat is created within $700 \mathrm{~m}$ of suitable diurnal habitats.

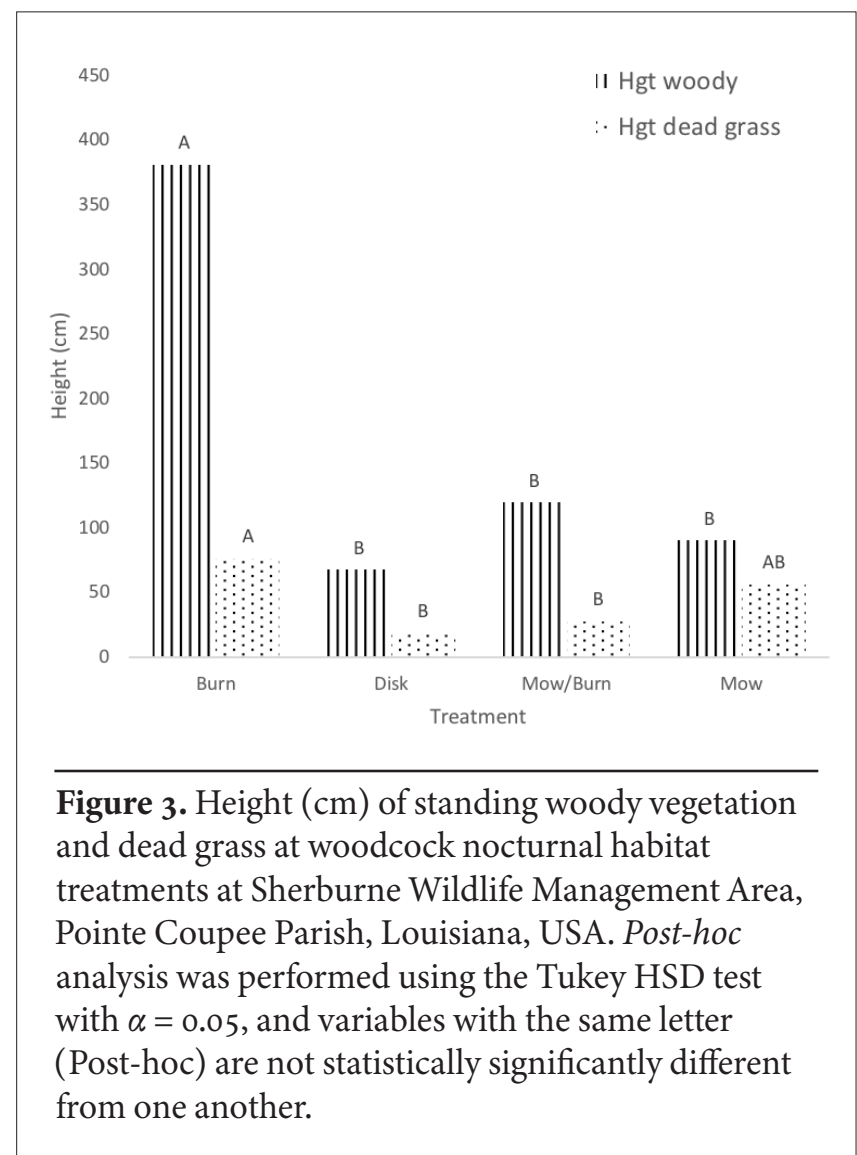




\section{Acknowledgments}

LDWF provided property and logistical support, and J. Bhattacharjee statistical advice. W. Futch, R. Elkharash, and M. Moore provided field assistance. Comments from D.G. Krementz improved an earlier version of this manuscript. Funding for this research was provided by the Louisiana Department of Wildlife and Fisheries PR W55$26 \&$ W55-27.

\section{Literature Cited}

Artmann, J.W., and L.D. Schroeder. 1976. A technique for sexing woodcock by wing measurement. The Journal of Wildlife Management 40:572-574.

Berry, C.B., W.C. Conway, R.M. Whiting Jr., and J.P. Duguay. 2006. Diurnal microhabitat use by American woodcock wintering in east Texas. Proceedings of the Tenth American Woodcock Symposium 10:63-75.

Berdeen, J.B., and D.G. Krementz. 1998. The use of fields at night by wintering American woodcock. The Journal of Wildlife Management 62:939-47.

Blackman, E.M., C.S. DePerno, R.W. Heiniger, M.J. Krachey, C.E. Moorman, and M.N. Peterson. 2012. Effects of crop field characteristics on nocturnal winter use by American woodcock. The Journal of Wildlife Management 76:528-533.

Blackman, E.M., C.S. DePerno, and M.N. Peterson. 2013. Use of crop fields and forest by wintering American woodcock. Southeastern Naturalist 12:85-92.

Dyer, J.M., and R.B. Hamilton. 1974. An analysis of feeding habits of American woodcock (Philohela minor) in southern Louisiana. Proceedings of the Fifth American Woodcock Workshop. University of Georgia, Athens, Georgia, USA.

Eyre, F.H. 1980. Forest cover types of the United States and Canada. Society of American Foresters, Washington, D.C., USA.

Glenn, J.R., R.M. Whiting, and J.P. Duguay. 2004. Microhabitat characteristics of nocturnal roost sites of American woodcock in east Texas. Proceedings of the Annual Conference of the Southeastern Association of Fish and Wildlife Agencies 58:302-311.

Harper, C.A. 2007. Strategies for managing early successional habitat for wildlife. Weed Technology 21:932-937.

Kelley, J.R. Jr., S. Williamson, and T.R. Cooper. 20o8. American woodcock conservation plan: a summary of and recommendations for woodcock conservation in North America. Compiled by the Woodcock Task Force, Migratory Shore and Upland Game Bird Working Group, Association of Fish and Wildlife Agencies. Wildlife Management Institute, Washington, D.C. USA. 162pp.
Krementz, D.G. 200o. Habitat management for wintering American woodcock in the southeastern United States. Proceedings of the Ninth American Woodcock Symposium 9:50-54.

Krementz, D.G., J.T. Seginak, D.R. Smith, and G.W. Pendleton. 1994. Survival rates of American woodcock wintering along the Atlantic coast. The Journal of Wildlife Management 58:147-155.

Krementz, D.G., J.T. Seginak, D.R. Smith, and G.W. Pendleton. 1995. Habitat use at night by wintering American woodcock in coastal Georgia and Virginia. Wilson Bulletin 107:686-697.

Krementz, D.G., R.C. Crossett, II, and S.E. Lehnen. 2014. Nocturnal field use by fall migrating American woodcock in the Delta of Arkansas. The Journal of Wildlife Management 78:264-272.

Louisiana Department of Wildlife and Fisheries. 2019. Sherburne WMA Description. <http://www.wlf.louisiana.gov/wma/2763>.

Martin, F.W. 1964. Woodcock age and sex determination from wings. The Journal of Wildlife Management 28:287-93.

Pace, R.M., III. 200o. Winter survival rates of American woodcock in south central Louisiana. The Journal of Wildlife Management 64:933-939.

Pace, R.M., III, M.W. Olinde, and F.G. Kimmel. 200o. Weight variation among American woodcock wintering in south-central Louisiana. Proceedings of the Ninth American Woodcock Symposium 9:90-95.

Rieffenberger, J.C., and R.C. Kletzly. 1967. Woodcock night-lighting techniques and equipment. U.S. Bureau of Sport Fisheries and Wildlife, Special Science Report -Wildlife, Number 101.

SAS Institute Inc. 2003. SAS version 9.1.2 for Windows software. Carey, North Carolina, USA.

Seamans, M.E., and R.D. Rau. 2016. American woodcock population status, 2016. U.S. Fish and Wildlife Service, Laurel, Maryland, USA.

Straw, J.A., Jr., D.G. Krementz, M.W. Olinde, and G.F. Sepik. 1994. American woodcock. Pages 97-114 in T.C. Tacha and C.E. Braun, editors. Migratory shore and upland game bird management in North America. International Association of Fish and Wildlife Agencies, Washington, D.C., USA.

Stribling, H.L., and P.D. Doerr. 1985. Nocturnal use of fields by American woodcock. The Journal of Wildlife Management 49:485-491.

U.S. Fish and Wildlife Service. 2004. Game bird below desired condition. <http://library.fws.gov/bird_publications/gamebirds_conditions.pdf $>$.

U.S. Shorebird Conservation Plan. 2001. U.S. Fish and Wildlife Service. <http://www.fws.gov/shorebirdplan/>.

Welch, J.R., D.G. Krementz, and J.B. Berdeen. 2001. Management of fields for nocturnal use by wintering American woodcock. Georgia Journal of Science 59:101-107. 